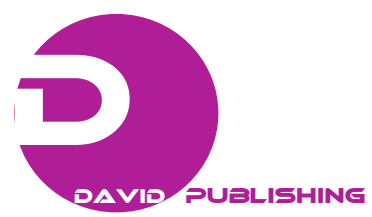

\title{
European Economic Integration and The Future of Southeastern European Countries
}

\author{
Karić Dušica \\ Alfa University, Belgrade, Serbia \\ Miodrag Paspalj, Nebojša Pušara \\ Belgrade Business School, Belgrade, Serbia
}

\begin{abstract}
Over the last few years major changes have happened in the region of South-Eastern Europe. They have been significantly determined by the changes in international political relations, and that mirrors economic and political interests of some countries. With its 27 member countries and the population of almost half a billion people, the EU is a significant factor on the world scene. The aim of this paper is to point out that the future of Southeast European countries is, undoubtedly, within the frame of European integration. Moreover, it shows that the EU accomplishes a dominant role in the global economic area. That is also indicated by economic relations of the EU with the South-East European countries, with special regard to Serbia, as it is elaborated in this paper. This paper also examined and compared relations in terms of GDP in South-East European countries, as well as the highest import and export by sectors in relation Serbia - the EU. For the purpose of this research, the information from the world economic data base was used as the parameter of the research, and the information from the relevant financial institutions in Serbia. The main findings showed which countries in the South-Eastern Europe have the highest economic potential, which countries had positive GDP growth rate, the fact that Serbia had export growth of goods and services towards the EU and all the difficulties which followed that export. Finally, taking into consideration all the parameters, it can be concluded that the goal and future of South-East European countries is within the EU integration.
\end{abstract}

Keywords: economic relations between the EU, countries with the greatest economic potential in the EU, the growth rate of GDP, the future of Southeast Europe

\section{Introduction}

The feature of contemporary world scene is a market that does not recognize traditional, time, and geographic limits. Creating new market rules, economic organisations are integrated, and products and services are internationalized and they emerge the local frame. The product of this kind of relation is opening national borders. Thus, national economies merge into regional economic organisations. In the sphere of global world

Karić Dušica, Doctor of economic sciences, Dean of the Faculty of Trade and Banking, Alfa University.

Miodrag Paspalj, Doctor of economic sciences, Assistant Professor, Belgrade Business School.

Nebojša Pušara, Doctor of economic sciences, Assistant Professor, Belgrade Business School.

Correspondence concerning this article should be addressed to Karić Dušica, Palmira Toljatija 3, 11070 Novi Beograd, Serbia. E-mail: dusica.karic@ftb.rs. 
economy, the need for inclusion in world economic flows of all market oriented countries is imposed. Especially important is the need for intensive exchange of goods, services, labour, and capital. For all Southeastern European countries, Serbia as well, the main challenge is joining The European Union. The challenges are primarily coordination of customs and other policies, institutions, and adjustment of these, mostly in transition, countries to the principles of market liberalization. Market liberalization brings many trade facilities, such as abolition of import and export customs, free movement of goods and capital, abolishing monopoly and greater competition bring lower prices and improvement of product and service quality for the final customers.

\section{The Evolution of European Integration}

The historical roots of the EU date back to the second world war when the idea of European unity gets its frame in signing international contracts and its material form through institutional internal and external functioning. However, the idea of European unity is much older and there was almost no period in the history of civilization from ancient times to the present that was not established on the present concept of the European Union, whether strategic political issues were in question or the cultural matrix European integration was based on.

The main idea of creating European integration is a desire to once and for all stop killings and destruction that happened in the war. It is obvious that the request for the member equality without dominance of countries or alliances is dominant through all the stated projects, with a special emphasis on the role of some particular countries responsible for the success of the entire process. Three countries are most frequently mentioned: Great Britain, Germany, and France, whether overcoming mutual conflicts is in question or leading role in European integration.

The significant impulse to European integration came from out of Europe, mainly from the USA. Surely the most famous instrument was so called as Marshall Plan, projected to help economic recovery of Europe destroyed in the war. The product of this strategy was formation of the Organisation for Economic Co-operation and Development (OECD), whose members mutually abolished trade barriers and promoted the concept of economic cooperation (Antevski, 2008). Nevertheless, the most important event in the post-war Europe was creation of the European council, whose aim was to create a system based on democracy, rule of law, respecting human rights and freedoms, and free market. Apart from the certain agreement with other integrating processes, The European council has managed to integrate a large number of European countries, some of which would later become an integral part of the European Communities, that is the European Union. In addition, very efficient judicial control of contractual duties appeared within this entity as a unique example of global proportions. Finally, another organisation plays an important role in the European integration process, even though it is an organisation with special organisational, functional, and strategic characteristics.

The Organisation for Security and Co-operation in Europe (OSCE) was formed in period after the end of The cold war in order to solidify cooperation process and overcome conflicts on Europe's territory, while the EU was formed precisely to avoid outbreak of internal conflicts through the economic and later political integration of member countries and the development of supranational institutions. The primary goal of establishing OSCE was to decrease tension between the divided blocs and enable free dialogue and mutual contacts in Europe. Further development of this organisation based on Helsinki Final Act, especially on parts concerning elaboration of their, so called, human dimension, considerably corresponds to the EU goals when it comes to security and 
political stability of Europe's territory where present and future members of the Union co-exist.

The EU shaping started through forming three European communities: the European Coal and Steel Community (ECSC), the Treaty of Paris 1951, the European Economic Community (EEC), The Treaty of Rome 1958 and The European Atomic Energy Community (EUROATOM), Special Treaty of Rome 1958. The European Union was established on 7 February 1992 in Dutch town Maastrich where 12 European countries (Belgium, Germany, France, Italy, Luxembourg, The Netherlands, Denmark, Ireland, Great Britain, Greece, Spain, and Portugal) signed the Treaty on European Union. As a reflection of new European dynamism, especially motivated by the Maastrich Treaty on European Union, Austria, Finland, and Sweden joined the European Union in 1995, so the number of its members from 12 to 15. The Maastrich Treaty on European Union, then the Treaty of Amsterdam, 2 October 1997, and the Treaty of Nice, 26 February 2001, improved the institutional structure of the EU, especially referring to functioning of the European Parliament, The European Council, The European Commission, The Court of Justice, and The Court of Auditors. Thus, the institutional links between all the members of the EU, whose laws directly concern the rights and duties of their members' citizens, were strengthened (Dašić \& Karić, 2009).

At European Union Summit, held in Copenhagen in December 2002, a decision was made to enlarge the EU with 10 new countries: Poland, Czech Republic, Slovakia, Slovenia, Hungary, Estonia, Latvia, Lithuania, Cyprus, and Malta. In accordance with The Treaty of Athens, signed on 16 April 2003, The European Union joined another 10 countries on 1 May 2004, so the number of its members went to 25. This enlargement was viewed as a starting point for creating "New Europe”. Bulgaria and Romania were admitted to The European Union on 1 January 2007, so the EU now has 27 member countries (Dašić \& Karić, 2009). Croatia is the 28th member country and its admission will be in 2013.

\section{The EU Economic Relations With Southeastern European Countries, With Special Regard to Serbia}

In conditions of more and more expressed globalization, regional and subregional cooperation, based on mutual interests and needs for regional partners, is becoming more significant. Basically it reflects the need for countries, with similar or even the same conditions of development or problems in realizing their reform goals, to join their forces and means in reply to global challenges. Regional integration connects a number of economies into an integral economic area on regional basis. Regional policy is one of the oldest EU policies, and led to achieving equal development on the whole territory of the EU by reducing and eliminating structural differences among the regions. Regional policy is based on solidarity, that is why a certain amount of money the members of the Union contribute to the joint funds goes to the less developed regions and social groups. Structural and cohesion funds serve for that purpose (Theo Hirtis, 2010). Long-term goal of every country is to join the European Union. In order for countries to achieve that goal it is necessary to meet the EU membership criteria, also known as Copenhagen criteria (political, economic, and accession criteria). Regional integration facilitates complying with these criteria and reduces the time which are necessary for the EU accession. Regional integration of the Southeastern European countries (SEE) is established in order to bring these countries closer to the EU membership through increased trade and political cooperation.

Southeastern European countries with the greatest economic potential are Croatia and Serbia, whereas IMF 
expects that Serbia's GDP will grow faster than Croatia's. There are figures for GDP per capita in Southeastern European countries, as well as the assessment of their tendencies by 2015 (see Table 1). The crisis hit all the countries, but the recovery (in terms of GDP per capita) was already significant in 2011. However, even though, e.g., Serbia records GDP growth of 1.5\% in 2010, because of the real undervaluation of dinar, GDP per capita dropped that year. By far, the highest GDP per capita has, as expected, Croatia, Serbia is in the middle, and Albania is at the tail.

Table 1

GDP Per Capita in Current International Dollars

\begin{tabular}{lrrrrrr}
\hline & \multicolumn{1}{c}{2010} & \multicolumn{1}{c}{2011} & \multicolumn{1}{c}{2012} & \multicolumn{1}{c}{2013} & \multicolumn{1}{c}{2014} & \multicolumn{1}{c}{2015} \\
\hline Albania & 3.616 & 3.720 & 3.932 & 4.165 & 4.437 & 4.765 \\
B \& H & 4.158 & 4.275 & 4.585 & 4.929 & 5.263 & 5.623 \\
Croatia & 13.528 & 13.872 & 14.572 & 15.381 & 16.238 & 17.146 \\
Macedonia & 4.635 & 4.868 & 5.204 & 5.532 & 5.885 & 6.242 \\
Montenegro & 6.117 & 6.197 & 6.530 & 6.883 & 7.163 & 7.443 \\
Serbia & 5.262 & 5.574 & 6.421 & 7.007 & 7.655 & 8.257 \\
\hline
\end{tabular}

Note. Source: World Economic Outlook Database (2010).

If we regard GDP per capita in relation to purchasing power (bln dollars), we get a slightly different picture because it incorporates the price level in each country. According to that indicator in 2010, Serbia had the largest economy in the Western Balkans (by the level of GDP it will become that only in 10 years time when it surpasses Croatia). Poorer countries have lower prices and it can be seen, if you divide the figures from the table by the number of citizens, that GDP per capita is roughly twice as big in most of the countries in question, while in Croatia that disparity is smaller (see Table 2).

Table 2

GDP Per Capita Based on Purchasing Power (Bln Dollars)

\begin{tabular}{lrrrrrrrr}
\hline & 2008 & 2009 & 2010 & 2011 & 2012 & 2013 & 2014 & 2015 \\
\hline Albania & 21.9 & 22.8 & 23.6 & 24.7 & 25.9 & 27.4 & 29.2 & 31.2 \\
B \& H & 30.5 & 29.8 & 30.2 & 31.5 & 33.5 & 35.8 & 38.1 & 40.5 \\
Croatia & 82.5 & 78.4 & 78.0 & 80.3 & 83.4 & 87.2 & 91.3 & 95.7 \\
Macedonia & 18.9 & 18.9 & 19.3 & 20.2 & 21.4 & 22.5 & 23.8 & 25.2 \\
Montenegro & 6.9 & 6.6 & 6.5 & 6.9 & 7.4 & 7.9 & 8.3 & 8.8 \\
Serbia & 79.8 & 78.1 & 79.9 & 83.3 & 88.7 & 95.0 & 101.9 & 109.0 \\
\hline
\end{tabular}

Note. Source: World Economic Outlook Database (2010).

According to IMF in 2010 all the countries, except Croatia, had positive growth rate (Albania 3.1\%, Croatia $-1.5 \%$, Montenegro 0.3\%, Macedonia 1\%, and B \& H 0.5\%). IMF expects that in the next five years the highest growth rates will have Serbia and Albania, while Croatia will have the lowest growth, which is consistent with the rule that the highly developed economies make slower progress. Serbia, by 2008, had extremely high current account balance of payments deficit (nearly 18\%), but it significantly dropped during the crisis and it was estimated that in 2010 it could be 8\%-9\% GDP. The countries in the region have also reduced relatively high balance of payments deficit: in 2010 current account balance of payments deficit was B \& H 6\%, Croatia 3\%, Albania around 11\%, and Montenegro 29\%. Montenegro has a very high balance of payments deficit as a result 
of huge capital inflow (compared with GDP on those territories) in the last few years and underdeveloped export sector as well.

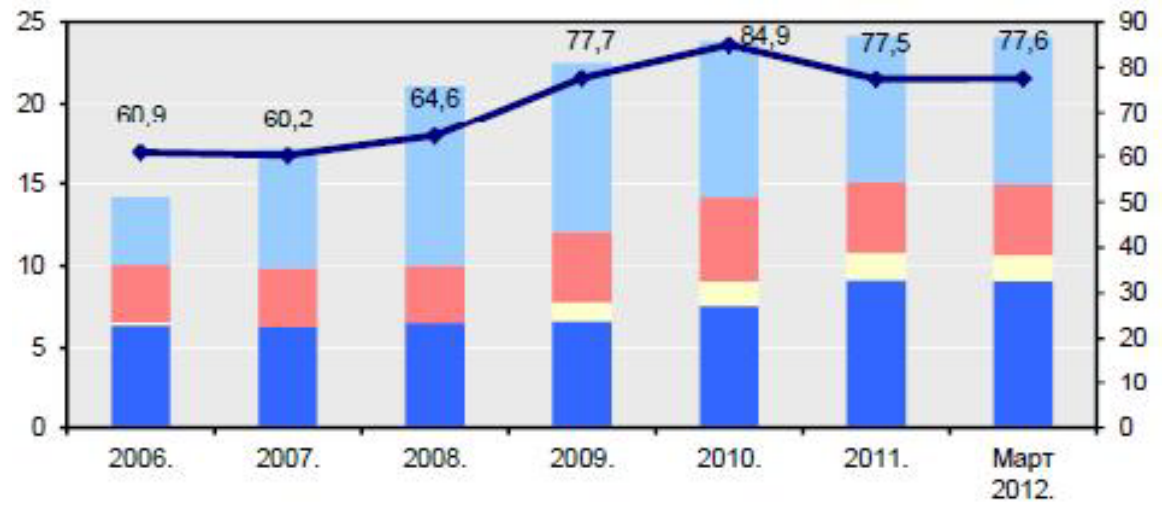

Figure 1. The Republic of Serbia’s external debt by GDP (EUR bln). Source: National Bank of Serbia.

Serbia's external debt, both public and private sector, as it can be seen from the previous chart is EUR 24.1 billion at the moment, and compared with the end of 2011 it dropped by EUR 57.6 million or $0.2 \%$. The external debt of the public sector dropped by EUR 118 million or 1.1\%, while the debt of the private sector increased by EUR 60.3 million or $0.5 \%$ respectively. Observed from the original due date the structure of the total external debt improved in the course of the first quarter-the share of short-term debt shrank from $2.7 \%$ in December 2011 to $2.4 \%$ as a result of a decrease in short-term debts of banks. The share of the external debt in estimated GDP, as the key indicator of the country's external solvency, edged up by 0.1 percentage point (pp) from end-2011 and settled at $77.6 \%$ at the end of the first quarter, which is below the level indicating high indebtness of $80 \%$ according to the World Bank criteria. The ratio of the external debt repayments of estimated GDP in the first quarter came to $12.4 \%$, of which $9.8 \%$ related to the repayment of the principal and $2.6 \%$ to the repayment of interest.

The increase in goods and service exports is a necessity due to the need to form maintainable growth of currency influx sufficient for regular external debt service and import payment. Dominant participation of the EU in Serbia's exports defines this regional integration as the key foreign trade partner in years to come. Almost 90\% of Serbia's exports goes to the EU market and to the countries' members of CEFTA. Nearly half of the exports to the EU is directed to three countries: Italy, Germany, and Slovenia. On the other hand, most of what is sold in CEFTA countries goes to the former Yugoslav republics Bosnia and Herzegovina, Montenegro, and Macedonia.

The main weakness of national exports to the EU market is its structure. High share of products classed into primary sectors tells more about aggravated exports of industrial products than it points to competitiveness of exports in the primary sector. Having in mind structural and dynamic characteristics of world trade demand, there is a necessity for quick adjustment of Serbia's exports to these demands. Technological delay or the national economy compared with the world economy makes it more difficult to reach the world market competition, so the primary goal should be radical restructured of real sector of the national economy. It can hardly be realized without significant influx of SDI, as new equipment and technology, which would accelerate structural change of the national production and lead to raising competitivenesss to a higher level. Hence, the requests for creating attractive ambience in Serbia which would motivate foreign investors to increase their direct investments to the 
national economy.

The possibilities of the global international market are certainly much bigger than we can offer or sell. The aim of every economy is to develop multiple activities, industry or services, agriculture, which help gain more means. If we want a constant growth of exports we have to improve the business environment and change the attitude towards economy, and only then enter the international economic scene. However, even when the goods from Serbia are competitive, no matter how processed they are, the results are often below our potential. The free trade agreement with Russia enables us to export more than $95 \%$ of our products to that country customs free, so our products have lower prices on the Russian market than the competition, which is not the case on the EU market. Three-fiths of Serbia’s exports make maize, raspberries, sugar, and base metals.

Table 3

Serbia's Main Exports-Partners in 2011

\begin{tabular}{ll}
\hline Country & Bln dollars \\
\hline Italy & 898.8 \\
Germany & 890.3 \\
Bosnia and Herzegovina & 780.5 \\
Montenegro & 602.7 \\
Romania & 574.4 \\
\hline
\end{tabular}

Note. Source: Chamber of Commerce and Industry of Serbia.

Table 4

Serbia's Exports-Sectors Bln Dollars

\begin{tabular}{ll}
\hline Sectors & Bln dollars \\
\hline Iron-steel & 58.3 \\
Coloured metals & 50.9 \\
Electric machines and appliance & 40.6 \\
Rubber products & 21.0 \\
Cork and wood products & 8.5 \\
Clothes & 26.2 \\
Footwear & 15.2 \\
Ready made products & 21.3 \\
Paper, cardboard & 15.1 \\
Road vehicles & 14.4 \\
\hline
\end{tabular}

Note. Source: Statistical Office of the Republic of Serbia January-September 2011.

Despite the tendency of exports growth, exporters face many problems and limitations. Principally, the most eminent difficulty is high interest rates on the national market, and companies run into debt only if necessary. Foreign banks favour financing national consumption. Restrictive monetary and credit policy (because of inflationary pressures) still diminishes banks’ credit potential, which in turn faciliates maintaining interest rates at high level. Active interest rates of commercial banks are especially high if we consider low passive interest rates on payed deposit. Deficiency of revolving funds for financing the production is followed by the deficiency of means to finance and secure exports, which restrains national exports from flourishing and prevents creating sustainable long-term tendency of its growth. To eliminate this limitation it is necessary to provide a suitable financial potencial of export credit and guarantee fund, and to improve the engagement of the state in promoting 
export economy (provide relevant funds in the budget for this purpose)

\section{Conclusions}

The EU reaches the final stage in shaping the integral market whose outlined vision was heralded less than five decades ago. Projects for creating an integral market consist of complex number of measures on institutional, economic, technological, and organisational level, whose realization should set up conditions for free circulation of goods, production factors-knowledge, labour, funds, in all of Europe. Integrational processes put the EU into a more competitive position compared with other economic entities in the world. Political decisions, measures, and activities on national level in business agglomeration face and are subordinated to that goal. These processes rightfully cause special attention and interest in the world, but also certain measures for the enlargement of the EU and the effects it will cause (and it is already causing) to be welcomed in a way of equal participation (having in mind its broader context) or at least in a way not to aggravate its own competitive position until the complete admission. The admission of countries in the integration processes is the main precondition for their economic growth. It is no longer a question that whether global-regional integration is necessary but how to make the existent relations more efficient and useful for all the participants. The EU is the example of how were, in relatively short period, created conditions for economic growth and application of democratic standards in new member countries. That is precisely why the future of Southeastern European countries belongs to the EU. The enlargement of the EU reduced the tension between the developed Western and underdeveloped Eastern Europe. The EU may be a good model for similar actions elsewhere.

\section{References}

Antevski, M. (2008). Regional economic integration in Europe. Beograd.

Baldwin, R., \& Wyplosz, C. (2009). The economics of European integration. Belgrade: Data status.

Baldwin, R., \& Wyplosz, Ch. (2004). The economics of European integration. New York: The McGraw-Hill.

Dašić, D., \& Karić, D. (2009). International economics and diplomacy basics. Belgrade.

Dinan, D. (2009). Ever closer union-The introduction to the European integration (p. 490). Belgrade: Službeni glasnik.

Drašković, V., \& Jovović, R. (2009). Globalization in the economic context. Belgrade.

Jovanović, M. N. (2004). European economic integration. Faculty of Economics, Belgrade.

Miščević, T. (2005). Joining the European union. Belgrade: The Economic and Social Research Institute.

Petković, T. (2009). Global economics and business policy. Čačak: Business School.

Theo Hirtis. (2010). The EU economics. Belgrade: The Economics and Finance Institute.

Trbović, A., \& Crnobrnja, M. (2009). The effects of Serbia's integration into the EU. Belgrade: FEFA.

Unković, M. (2009). International economics. Beograd: Univerzitet Singidunum.

Venables, A. J. (1999). Regional integration agreements: A force for convergence of divergence. World Bank Working Papers, No. 2260.

Zdravković, M. (2006). The degree of correspondence and complementary of the export offer between Serbia and South-East European countries. Central European Countries and the EU Import Demand. 